\title{
On Forty Years: Remarks from the Editor
}

\author{
Daniel G. Bates
}

Published online: 17 February 2012

(C) Springer Science+Business Media, LLC 2012

Human Ecology: An Interdisciplinary Journal was launched by Plenum Corporation in March 1972 with four articles: Stewart Oden'hal (on the bioenergetics of Indian cattle), Clifford Geertz (on traditional irrigation in Bali and Morocco), Bernard Nietsmann (on fishing among the Miskito Indians) and Kenneth Cairk (on environmental decision making), each of which became widely cited and, together with the contents of the three following numbers, could easily be offered as a fine introduction to the interdisciplinary study of humanenvironmental interactions as generally framed in 1972. The Editors' Introductory Statement described their intention to publish research on " $\ldots$ the role of social, cultural, and psychological factors in the maintenance of ecosystems; effects of population density on health, social organization, environmental quality; new adaptive problems in urban environments; interactions of technological and environmental change; and the genesis of maladaptations in man's biological and cultural evolution ..." (1971:1).

The last issue for the 39th year of Human Ecology's uninterrupted publication, December 2011, contains ten articles and five book reviews. The articles comprise, in brief, a model of modern human-Neanderthal interactions; an examination of differential fertility among Native Americans with African ancestry; a study of illegal sea turtle hunting in Baja California, Mexico; a report on cetacean by-catch in the Korean Peninsula; traditional ecological knowledge of Swiss Alpine farmers; conservation and the management of sacred groves of India; ecological conditions and mortality in nineteenth-century Poznań, Poland; the costs of amphibian conservation in urban environments in Northern Spain; traditional use of plants for handicrafts in Southeastern Europe; cross-cultural agreement

D. G. Bates $(\square)$

New York, USA

e-mail: dbates@hunter.cuny.edu in perceptions of animal beauty: boid snakes; and an inquiry into the question of whether a Baconian vision of nature dominates among researchers in ecology.

Lines of both continuity and change are evident in just this small sample; the interdisciplinary basis for inquiry and breadth of interest characterize these numbers and each of the intervening issues. Anthropologists, geographers, sociologists, demographers, natural scientists and others tackle diverse subjects across the globe while communicating in a manner that is largely accessible to all. At the same time, reflecting developments in society at large as well as the cumulative nature of intellectual capital, researchers today routinely use concepts and instruments of measurement unformulated 40 years ago. For example, Barton et al.'s 2011 study of archaic human interactions (Vol. 39 No 6) relies on both innovative mathematical tools and DNA data recently extracted from fossil Neanderthal remains; and Brown et al.'s 2007 report on hunter-gathers optimizing their foraging patterns (Vol. 35 No 1) uses Lévy flights, a statistical innovation within optimal foraging theory. Glover's 2009 archaeological study of the settlement of western silver mining towns in nineteenth century America (Vol. 37 No 5) utilizes central place foraging theory as well as formal economic models to account for the "irrational exuberance" which led to settlement growth far beyond anything warranted by local resources.

One significant change in intellectual tenor is that a generation ago, researchers often implicitly or explicitly asked how individual behavior or cultural practice enabled a population to maintain itself in a specific environment. Thus the original stress by the editors on ecosystem maintenance or disruption. Today there is greater emphasis on the problems facing individuals and how actors deal with them with the consequence that there is much more attention to decision-making at the individual level as people strategize and optimize risk, costs and benefits within specific contexts. Rather than attempting 
to formulate a cultural ecology or even a specifically "human ecology" model, researchers more often draw on demographic, economic and evolutionary theory as well as upon models derived from field ecology.

Foremost in terms of evident long-term continuity is the preponderance of research rooted in close, empirical observation. Not infrequently scholars report on field research of long duration, often conducted under arduous conditions. Many, if not most, $H E$ contributors can be aptly characterized as the foremost experts in their particular area of study, especially where their work entails participant observation. ${ }^{1}$ In many ways work appearing in the Journal is closer to ecology as slow journalism rather than a quest for quick answers or explanation in terms of system function.

In the 39 years culminating in 2011 Human Ecology has published 1,106 feature articles contributed by 2006 authors, as well as commentary and 248 book reviews. The output of published scholarship increased gradually over the first 30 years with a regularly enhanced page budget provided by Plenum Publishing Corp within the initial quarterly format. Ten years ago this changed dramatically. In 2004, Plenum's successor, Kluwer Publishing, supported a move to six numbers annually and, in 2007, under Springer Academic's ownership, trim size was increased to accommodate our present average of 10 to 12 articles per print issue. Thus the years 2005-2008 marked a major transition with not only more research in print but also greatly enhanced global visibility.

This chart shows distribution of Human Ecology readership in 2011 by geographic region.

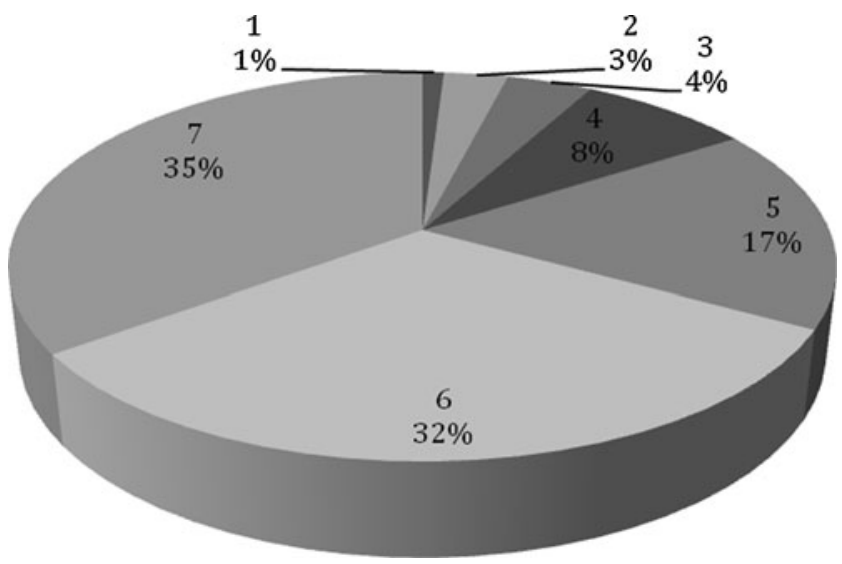

1. Oceania, 2. Africa, 3. South America, 4. Australia, 5. Asia, 6. Europe, 7. North America

\footnotetext{
${ }^{1}$ One example among many: Hirokazu Yasuika off and on over 3 years lived with the Baka of the Congo Basin closely monitoring the dietary content derived from foraging and hunting in order to see how such practices could fully exploit the world's vast tropical forests without access to Neolithic levels of agriculture (Vol. 34 No 2 2006).
}

Just how successfully the journal fulfills its mission is evident in numerous ways: $H E$ is listed by 88 abstracting and indexing services; the publisher regularly circulates press releases and a number of recent ones have attracted worldwide press coverage. ${ }^{2}$ Two independent rating organizations rank its impact compared with other journals. SCImago Journal Rank (SJR) ranks 18,000 scientific journals worldwide representing all scientific disciplines, and positions Human Ecolo$g y$ among the first 5,000 (the first 4,000 are mostly medical and biological journals). SJR measures of the Journal's relative impact in its field are based on the number of citations and number of articles per publication year. For more information, visit: http://www.scimagojr.com/index.php

Here is the 2011 SJR ranking of Current Anthropology (0.128), Human Ecology (0.064), and American Anthropologist (0.045).

\begin{tabular}{ll}
\hline Journal & Anthropology \\
\hline Current Anthropology 0.128 & Ranks 4/104 \\
Human Ecology 0.064 & Ranks 9/104 \\
American Anthropologist 0.045 & Ranks 12/104
\end{tabular}

As for impact factor ratings within disciplines, according to Thompson-Reuters ISI for 2010, $H E$ ranks 8 out of 75 among journals in anthropology; in environmental studies it ranks 17 out of 77; and in sociology it ranks 8 out of 129 . This is a significant feat for a journal that in 1972 set itself apart from disciplinary approaches. The following table presents Human Ecology rankings by SJR (0.074) and Thompson-Reuters ISI (1.923) in 2010.

\begin{tabular}{ccccc}
\hline $\begin{array}{c}\text { Ranking } \\
\text { institution }\end{array}$ & Anthropology Sociology & $\begin{array}{c}\text { Environmental } \\
\text { science } \\
\text { (misc) }\end{array}$ & $\begin{array}{c}\text { Social } \\
\text { Sciences } \\
\text { (misc) }\end{array}$ \\
\hline $\begin{array}{c}\text { SJR, } \\
\text { indicator } \\
\text { for } 2010\end{array}$ & $\begin{array}{c}9 \text { out } 104 \\
\text { of }\end{array}$ & $\begin{array}{c}13 \text { out } \\
\text { of } 459\end{array}$ & $\begin{array}{c}80 \text { out } \\
\text { of } 259\end{array}$ & $\begin{array}{c}19 \text { out of } \\
372\end{array}$ \\
$\begin{array}{l}\text { ISI, impact } \\
\text { factor for }\end{array}$ & & & & \\
2010 & & out of 75 & out 129 & 17 out \\
of 77 & n/a \\
1.923 & & & \\
\hline
\end{tabular}

This chart shows changes in impact factor calculated for Human Ecology by Thompson-Reuters ISI from 2003(0.829) to 2010 (1.923).

\footnotetext{
${ }^{2}$ For example see Aporta, C. Vol. 37 No 2; Glover, S. Vol. 37 No 5; Bouby, L. et al. Vol. 39 No 3; Barton et al. Vol 39 No 6; Logan Vol. 39 No 6 .
} 


\section{ISI impact factor 2003-2010}

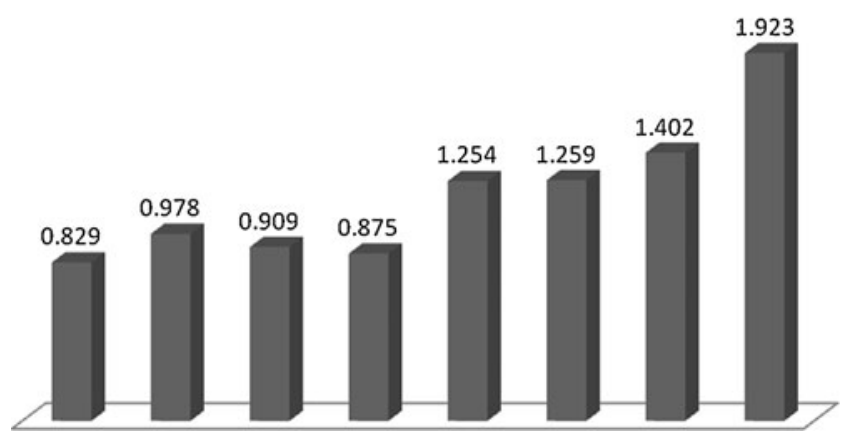

The 5-Year ISI Impact Factor announced in 2010 was 2.249

Thomson-Reuters ScienceWatch, gives $H E$ a citation impact score for 2001-2011 of 6.65, which places it 11 out of 20 of the top journals in anthropology. By comparison, Current Anthropology is in 6th place and American Anthropologist is in 13th place.

\begin{tabular}{lllll}
\hline Journal & Papers & Citations & Impact & Rank \\
\hline Current Anthropology & 480 & 4,367 & 9.1 & 6 \\
Human Ecology & 327 & 2,176 & 6.65 & 11 \\
American Anthropologist & 588 & 3,195 & 5.34 & 13 \\
\hline
\end{tabular}

The current acceptance rate is between $18 \%-20 \%$ and 240 manuscripts were submitted in 2011. According to Springer's figures, the daily article download rate ranges between 300 and 1,000 per day (over 80,000 in 2011).

Turning briefly to the history of the journal, Andrew P. Vayda, Pete to all and sundry, was recruited in 1970 by Seymour Weingarten at Plenum Press to be the founding editor. Seymour's vision was for a new journal which explicitly disavowed discipline-limited approaches as self-defeating. Pete was very much aware of the birthing difficulties that a new academic journal must face, let alone one with such a mission and that was therefore not attached to an existing professional institution. At that time ecology and the environment were very much growing concerns among social scientists. The challenge was to bring together research that would normally be apportioned among discipline rooted venues. To overcome this, Pete drew on his extensive personal network to attract distinguished scholars to the editorial board and to persuade them to submit articles. The initial board of editors included not only internationally renowned researchers but also academics who were very much the public face of environmental awareness, such as Rene Dubos and Barry Commoner. Very rapidly the journal attracted more acceptable submissions than it had a budget to print. In short, it lived up to the promise of providing a forum for problem oriented, empirically researched articles.

In 1976 Pete asked Susan Lees to take over the editorship as he was increasingly involved with overseas projects. Susan, due to her own commitments, in turn invited me to be co-editor with her. By that time Human Ecology was an established, peer-reviewed journal, and it has been housed at Hunter College, C.U.N.Y. in the Department of Anthropology ever since this move. The journal grew steadily even though by the late 1970s ecological treatment of social or cultural behavior was seemingly declining. Mainstream disciplinary journals, in anthropology at least, such as the American Anthropologist, were publishing fewer articles based on research rooted in empirical evidence utilizing environmental variables. As a consequence, social scientists committed to empirical studies found $H E$ a particularly welcome venue, perhaps even a relief from the prevailing often ideologically driven discussion.

In 1998 Susan became co-editor of the American Anthropologist and I remained editor-in-chief of Human Ecology. Since its inception the journal has critically relied on a number of very talented editorial assistants, mostly working part-time while pursuing graduate studies. One exception was that in 1992 Judith Tucker, who holds a degree in anthropology and linguistics from London University, took on major responsibility for editorial services. She continues overseeing the copyediting and language aspects of submissions, important components of the editorial process since many authors are not native speakers of English. In 1998 Ludomir Lozny, a professional archaeologist, joined the journal and shortly thereafter was named Managing Editor, creating the basis of the current editorial team. During his tenure the journal, as noted, moved from four to six issues a year, a significantly increased page budget, larger tear size and with author-supplied four-color cover photographs. The unsung heroes of the enterprise are the academic reviewers without whose unpaid and usually unacknowledged efforts, the journal could not maintain its standards.

The journal has had an active book review section from the beginning, starting with editors Edwin Cook and William Davis, followed by Bonham Richardson, Larry Grossman and Nancy Flowers, to name only those who served lengthy terms. Our current very energetic book review editor, Flora E. Lu, has herself published frequently in the journal. As noted earlier, Plenum Press was acquired by Kluwer in 1999, which in turn was taken over by Springer Academic in 2005. In 2007 Springer agreed to bring out a Book Series under the general editorship of Ludomir Lozny and myself: Studies in Human Ecology and adaptation, 
which shares an Editorial Board with $H E$. Seven volumes have appeared in this series to date, with most going into multiple printings. A new series under the same editorship was approved in 2011: Springer Briefs in Human Ecology, which will publish shorter volumes in paperback of ca. 40,000 words. We hope to sign our first volume in 2012. Since 1999, our very able and very supportive publisher's supervising editor has been Teresa Krauss. Our distinguished Editorial Board members have been critical in maintaining the high standards of the journal, although often do not get the individual credit they richly deserve. 